\title{
De effectiviteit van interventies ter stimulering van gezonde voeding
}

\author{
K.I. Proper • I . Bakker • K. van Overbeek • \\ M.W. Verheijden • W. van Mechelen
}

Samenvatting Dit artikel betreft de laatste in een reeks van vier artikelen, waarin een overzicht wordt gegeven van de beschikbaarheid en effectiviteit van (primair) preventieve leefstijlinterventies, toepasbaar in de bedrijfsgezondheidszorg. Dit artikel gaat over voeding. Op basis van het literatuuronderzoek wordt geconcludeerd dat voedingsinterventies gericht op het verbeteren van de groente- en fruitconsumptie en/of op het verminderen van de vetconsumptie effectief zijn op de consumptie van groente en fruit, respectievelijk de inname van vet. Interventies gericht op gezonde voeding hebben uitsluitend een gunstig effect op lichaamsgewicht indien de interventie tevens gericht is op andere leefstijlaspecten, waaronder voornamelijk stimulering van meer bewegen en kunnen daarmee bijdragen aan de preventie van overgewicht. Het bewijs voor een effect op bloeddruk, cholesterolgehalte en werkgerelateerde uitkomstmaten ontbreekt vooralsnog, mede als gevolg van het beperkte aantal onderzoeken op dit terrein. In Nederland zijn diverse partijen actief in het ontwikkelen van voedingsinterventies. Gedegen evaluaties van deze interventies vinden echter nauwelijks plaats. Aangezien arbodiensten weinig tot geen ervaring hebben in het inzetten van

\section{K.I. Proper $(\varangle)$}

Dr. Karin Proper en prof.dr. Willem van Mechelen werken beiden bij VU medisch centrum, Afdeling Sociale

Geneeskunde, EMGO Instituut, Amsterdam.Dr.ir. Ingrid

Bakker en drs. Kerstin van Overbeek werken beiden bij TNO

Kwaliteit van Leven, Preventie en Zorg, Leiden.Dr.ir. Marieke Verheijden werkt bij TNO Kwaliteit van Leven | Arbeid,

Hoofddorp.De eerste drie hier genoemde auteurs werken ook

bij Body@Work, onderzoekscentrum Bewegen, Arbeid en

Gezondheid, TNO-VUmc, VU medisch centrum, Amsterdam.

Correspondentieadres: Dr. Karin I. Proper, VU medisch

centrum, Afdeling Sociale Geneeskunde, EMGO Instituut,

Van der Boechorststraat 7, 1081 BT Amsterdam. E-mail:

ki.proper@vumc.nl. interventies ter stimulering van gezonde voeding, is het wenselijk dat richtlijnen ontwikkeld worden waarbij rekening wordt gehouden met de haalbaarheid in de bedrijfsgezondheidszorg.

Keywords literatuuroverzicht - effectiviteit . interventies · voeding bedrijfsgezondheidszorg . primaire preventie

De belangstelling voor gezonde voeding is de afgelopen jaren toegenomen. Reden hiervoor is onder meer de dramatische toename van (ernstig) overgewicht. In 2003 had $46,1 \%$ van de Nederlandse bevolking van 20 jaar en ouder overgewicht, waarvan $10,7 \%$ ernstig overgewicht (obesitas), tegenover 36,4\% respectievelijk 6,1\% in 1993 (bron: CBS). Overgewicht is een belangrijk volksgezondheidsprobleem gezien de verhoogde kans op harten vaatziekte, Diabetes Mellitus type 2, bepaalde soorten van kanker (dikkedarmkanker bijvoorbeeld), maar ook op klachten aan het bewegingsapparaat en psychische klachten, die de twee belangrijkste oorzaken van ziekteverzuim vormen. Er zijn tevens aanwijzingen dat werknemers met overgewicht vaker een arbeidsongeschiktheidsuitkering ontvangen, minder productief zijn en vaker verzuimen van het werk. ${ }^{1,2}$

Naast het effect van gezonde voeding op overgewicht levert het bevorderen van gezonde voeding ook een algehele gezondheidswinst op. Drie belangrijke voedingscomponenten zijn de inname van groente en fruit, voedingsvezels, en vet. Met betrekking tot de definitie van 'gezonde voeding' zijn Nederlandse en internationale richtlijnen opgesteld. Het is echter bekend dat de meerderheid van de Nederlanders niet voldoet aan deze aanbevolen hoeveelheden. ${ }^{3,4}$ 
De werkplek is een geschikte setting voor het bevorderen van gezond gedrag, zoals het eetgedrag, omdat het gros van de werknemers ongeveer $60 \%$ van hun werktijd doorbrengt op de werkplek en daarmee gemiddeld ten minste één maaltijd per dag op het werk nuttigt. Dit biedt kansen voor het bedrijf om het gebruik van gezonde voeding onder haar medewerkers te stimuleren. Dit artikel gaat in op voedingsinterventies die door de bedrijfsgezondheidszorg ingezet kunnen worden.

1. Werknemers met overgewicht verzuimen vaker en zijn minder productief.

2. De bedrijfsarts kan een belangrijke en effectieve rol spelen bij het voorkomen van overgewicht door het stimuleren van gezonde voeding in combinatie met meer lichaamsbeweging.

\section{Vraagstelling}

De specifieke vraagsteling van het literatuuronderzoek was:

Wat is bekend over de (kosten-)effectiviteit van eerstelijnsinterventies ter stimulering van gezonde voeding op gedrags-, gezondheids- en werkgerelateerde uitkomstmaten?

\section{Methode}

\section{Literatuuronderzoek}

Er is naar literatuur gezocht in Medline (via Pub- Med), PsycInfo, OSH-ROM en Online Contents, waarbij een selectie is gehanteerd van Nederlandstalige en Engelstalige publicaties vanaf 1984 tot en met 2004. Naast een computergestuurde zoektocht is in persoonlijke bestanden gezocht naar relevante artikelen en is het sneeuwbaleffect toegepast. Voor de uiteindelijke selectie van literatuur is een aantal criteria opgesteld. De gehanteerde in- en exclusiecriteria staan vermeld in Box 1.

\section{Box 1 Gehanteerde in- en exclusiecriteria Onderzoe- ken moesten aan de volgende inclusiecriteria voldoen:}

1. Datum van publicatie tussen 1 januari 1984 en 1 maart 2004.

2. Het artikel is geschreven in het Nederlands of Engels.

3. Gehanteerde zoektermen betroffen: (nutrition OR diet* OR food) AND (intervention OR program*) AND (effect OR evaluation).

4. De interventie is gericht op het stimuleren van gezonde voeding.
5. De interventie is gericht op primaire preventie; de onderzoeksgroep bestaat uit een gezonde populatie, d.w.z. geen gezondheidsklachten of verhoogd risicoprofiel op basis waarvan zij gestimuleerd worden gezonder te eten.

6. De interventie is ontwikkeld voor de eerste lijn en toepasbaar in de bedrijfsgezondheidszorg.

7. Het onderzoek heeft een (gerandomiseerde) gecontroleerde opzet.

8. Het effect van de interventie wordt geëvalueerd d. m.v. een voor- en ten minste één nameting.

9. Leeftijdscategorie 16-65 jaar (werkende populatie).

10. Uitkomstmaat is gedrags-, gezondheids- of werkgerelateerd, bijvoorbeeld: voedingsgedrag (consumptie fruit, groente, vezels, vetten, e.d.), bloeddruk, cholesterol, lichaamsgewicht, of ervaren gezondheid, ziekteverzuim, productiviteit, werktevredenheid of ervaren werkstress.

\section{Onderzoeken zijn op basis van de volgende exclusie- criteria verwijderd:}

1. Observationele onderzoeken.

2. De interventie is gericht op secundaire of tertiaire preventie. Bijvoorbeeld als de interventie gericht is op het bestrijden van een reeds aanwezige ziekte d.m.v. stimulering van gezonde voeding.

3. De doelgroep bestaat uit mensen met een verhoogd risicoprofiel of met reeds aanwezige gezondheidsklachten.

4. D e doelgroep bestaat uit jeugd (0-16 jaar) of ouderen $(65+)$.

\section{Inventarisatie veldpartijen}

Er zijn gesprekken gehouden met een aantal veldpartijen die actief zijn op het gebied van voeding( sinterventies). Ook is met een drietal arbodiensten (waarvan twee grote interne arbodiensten) gesproken over wat zij reeds doen op het terrein van leefstijl, waaronder het stimuleren van gezonde voeding. Doel van deze gesprekken was het inventariseren van wat er reeds in Nederland gebeurt op het gebied van ontwikkeling, implementatie en/of evaluatie van interventies ter stimulering van een gezonde voeding. De ondervraagde veldpartijen waren: het Voedingscentrum, het Nationaal Instituut voor Gezondheidsbevordering en Ziektepreventie (NIGZ, Programma Werk \& Gezondheid), de Nederlandse Hartstichting (NHS), de Nederlandse Zuivel Organisatie (NZO), KLM Arboservices, de Nederlandse Spoorwegen (maakt gebruik van de diensten van ArboUnie) en ArboNed. 
Tabel 1 Zoekstrategie voor het opsporen van eerstelijnsinterventies ter stimulering van gezonde voeding

\begin{tabular}{lcr}
\hline Database & Zoektermen & Aantal treffers ('hits') \\
\hline PubMed & (nutrition OR diet* OR food) AND (intervention OR program*) AND (effect OR evaluation) & \\
PsycInfo & (nutrition OR diet*) AND intervention AND effect & 401 \\
OSH-ROM & (nutrition OR diet*) AND intervention AND effect & 101 \\
Online & (nutrition OR diet*) AND intervention AND effect & \\
$\quad$ Contents & & 50 \\
Totaal & & \\
\hline
\end{tabular}

\section{Resultaten}

\section{Literatuuronderzoek}

De literatuurzoektocht leverde in eerste instantie 696 hits op (tabel 1). Door het zoeken in diverse bestanden zaten hier nog veel onderzoeken dubbel in. Ook bleek op basis van de samenvatting een groot aantal gevonden onderzoeken niet aan de inclusiecriteria te voldoen. Uiteindelijk zijn 44 publicaties betreffende 37 onderzoeken geselecteerd, waarvan 27 RCT's en 10 CT's. Gezien de beschikbaarheid van veel RCT's, die methodologisch gezien waardevoller zijn dan enig ander type onderzoeksdesign, is bij de beschrijving van de effectiviteit van de interventies gebruikgemaakt van de uitkomsten van de RCT's, met uitzondering van onderzoeken naar de effectiviteit op bedrijfsrelevante uitkomsten (1 CT).

\section{Type interventies}

In vrijwel alle interventies is gebruikgemaakt van voorlichting: individueel, groepsgewijs of door middel van massamedia. Ook het geven van feedback over de eigen voedingsconsumptie kwam regelmatig voor, met als doel het verhogen van het bewustzijn over het eigen (ongezonde) eetgedrag. In een enkel onderzoek bestond de interventie uit veranderingen in de bedrijfsomgeving. 14,22,23 De voedingscomponenten die vooral aan de orde kwamen, waren groente en fruit, vet, en vezels. Alhoewel de meeste onderzoeken (19 van de 27 RCT's) alleen gericht waren op het stimuleren van gezonde voeding ${ }^{6-14,16-19,21-23,26,27,29,32 ~(m o n o c o m p o n e n t i e e l), ~ w a s ~}$ een aantal ook gericht op andere leefstijlfactoren zoals lichaamsbeweging, roken of alcohol $15,20,24,25,28,30,31,33$ (multicomponentieel). Gedetailleerde informatie over de onderzoeken en de onderzochte interventies staat beschreven in tabelvorm in het Body@Work rapport (http://www.bodyatwork.nl/files/rapport_bravo.pdf).

\section{Effectiviteit op voedingsgedrag}

In totaal zijn 23 RCT's (24 publicaties) met voedingsgerelateerde uitkomsten gevonden.6-29 Deze uitkomstmaten zijn onderverdeeld in drie categorieën: groente en fruit, vet, en voedingvezels. In 16 RCT's is naar het effect op de consumptie van groente en fruit gekeken, waarbij het aantal porties fruit en/of groente als uitkomstmaat werd gehanteerd. 6-22 In het merendeel van deze onderzoeken $(n=12)$ zijn significant positieve effecten gevonden. 6,7,12-22 Deze onderzoeken hadden een interventieperiode variërend van 6-9 weken ${ }^{7}$ tot $1,5-2$ jaar. ${ }^{6,14,15,16,20,22}$ Verder vonden drie onderzoeken een positieve trend (niet significant). ${ }^{10,11,14}$ In één van deze onderzoeken 14 werd een 1,5 jaar durende bedrijfsinterventie vergeleken met een gecombineerde bedrijfs- en gezinsinterventie, waarbij vooral de laatste effectief bleek. Bij drie andere onderzoeken $^{16,18,20}$ was een gemengd beeld zichtbaar, waarbij deels een positief effect is gevonden en deels geen effect. Tot slot lieten twee van de 16 onderzoeken geen enkel effect van een computergestuurde voorlichtingsinterventie of een algemene voorlichtingsinterventie zien op de dagelijks geconsumeerde porties groente en fruit direct na de interventie ${ }^{8}$ of 4 maanden na het toesturen van een voorlichtingspakket. ${ }^{9}$ Deze twee onderzoeken betroffen beide een kortdurende monocomponentiële interventie, te weten 2-3 weken computergestuurde feedback ${ }^{8}$ en een éénmalig computergegenereerd voorlichtingspakket. ${ }^{9}$

In 15 RCT's zijn uitkomsten gerapporteerd over de consumptie van vet. ${ }^{7-10,15,16,18,20,23-29}$ Effectmaten betroffen de inname van vet of verzadigd vet in gram per dag, energie \% uit (verzadigd) vet of een vetscore gemeten aan de hand van diverse vragen. Dertien van deze onderzoeken lieten significant positieve effecten zien op de inname van vet of het energie $\%$ uit vet. 7-10,15,16,18,20,23,26-29 De overige twee onderzoeken ${ }^{24,25}$ vonden weliswaar een positieve trend op de inname van vet, maar het verschil was niet significant. Deze laatste twee onderzoeken evalueerden het effect van een éénmalige multicomponentiële interventie met een effectmeting na 6 maanden,24 en een 1,5 jaar durende interventie gericht op gedragsverandering met betrekking tot de inname van vet en cholesterol, en tevens gericht op stimulering van bewegen. ${ }^{25}$ De meeste interventies vonden plaats in de eerste lijn. Een deel vond echter plaats in de werksetting en bleek eveneens effectief te zijn. De interventies maakten gebruik van diverse vormen van 
voorlichting. Soms waren dat groeps- of voorlichtingsbijeenkomsten, maar veelal betrof het een individueel advies (voorlichtingop- maat). In het onderzoek van Campbell et al. ${ }^{9}$ was voorlichting-op-maat vergeleken met het verstrekken van algemene informatie. De voorlichting- op-maat bleek daarbij effectiever op vermindering van de vetconsumptie. Deze voorlichtingop- maat bleek echter niet effectief op de consumptie van groente en fruit (zie vorige paragraaf). In de onderzoeken van Kreuter en Strecher. ${ }^{24}$ en De Bourdeaudhuij en Brug ${ }^{26}$ is voorlichting-op-maat vergeleken met het verstrekken van algemene informatie; ook daar bleek de voorlichting-opmaat effectiever.

Verder is gekeken naar het effect van voedingsinterventies op de inname van vezels. Hierover hebben zes RCT's gerapporteerd, ${ }^{10,15,16,23,27,29}$ die een enigszins gemengd beeld lieten zien. Drie onderzoeken vonden significant positieve effecten op de vezelinname. ${ }^{16,27,29}$ Eén van deze onderzoeken 27 vond van het éénmalig aangeboden zelfhulpprogramma in de vorm van brochures verstrekt door de huisarts zowel na 3 als na 12 maanden een significant positief effect op een zogenoemde vezelscore en een positieve trend op de vezelinname uitgedrukt in $\mathrm{g} / 1000 \mathrm{kcal}$. Verder was in het onderzoek van Sorensen et al., ${ }^{23}$ waarbij tevens de werkomgeving veranderd was, geen effect gevonden op de vezelinname van het voorlichtingsprogramma via de werkplek. Een ander onderzoek van Sorensen et al., ${ }^{15}$ eveneens uitgevoerd in de werksetting, vond alleen een positieve trend in de vezelinname onder werknemers en geen verschillen tussen de onderzoeksgroepen: kantoorwerknemers, hoger opgeleiden en managers. Tot slot werd één keer een negatieve trend gevonden, waarbij de interventiegroep (niet significant) minder vezels is gaan consumeren en de controlegroep (niet significant) meer. ${ }^{10}$

Ten slotte is in twee RCT's het effect op de energieinname (in $\mathrm{kcal} / \mathrm{dag}$ ) onderzocht. ${ }^{10,25}$ Het onderzoek van Abood et al. ${ }^{10}$ onderzocht een 8 weken durende voorlichting-op-maat (monocomponentieel) en vond direct na afloop een significant gunstig effect met een afname van $837 \mathrm{kcal} / \mathrm{dag}$ in de interventiegroep tegenover een lichte toename van $28 \mathrm{kcal} / \mathrm{dag}$ in de controlegroep. Het tweede onderzoek betrof een interventie gericht op de inname van vet en cholesterol alsmede stimulering van bewegen en vond een afname in de energie-inname in beide onderzoeksgroepen: $722 \mathrm{~kJ} / \mathrm{dag}$ in de interventiegroep en 421 $\mathrm{kJ} /$ dag in de controlegroep. ${ }^{25}$

Effectiviteit op gezondheidsger3elateerde uitkomstmaten

Er zijn tien RCT's gevonden die het effect van een voedingsinterventie, hoofdzakelijk gericht op het verlagen van de vetconsumptie en het verhogen van de consumptie van groente en fruit, hadden onderzocht op gezondheidsgerelateerde uitkomstmaten. ${ }^{19,20,25,27,28,30-33}$ De uitkomstmaten zijn verdeeld in de volgende categorieën: gewicht (of een daaraan gerelateerde maat), bloeddruk en cholesterol. Effecten op gewicht (en daaraan gerelateerde maten, zoals Body Mass Index (BMI) of vetmassa) zijn gemeten in acht RCT's. ${ }^{19,20,25,27,28,30,31,33}$ Een aantal onderzoeken had meer effectmaten gehanteerd, of het effect van de interventie op gewicht op meerdere meetmomenten gemeten. In vijf onderzoeken zijn significant positieve effecten gevonden, ${ }^{20,25,30,31,33}$ in twee onderzoeken is een positieve trend gerapporteerd ${ }^{20,28}$ en in drie onderzoeken is geen effect gevonden. ${ }^{19,25,27}$ Twee onderzoeken lieten inconsistente resultaten zien. Zo bleek in het onderzoek van Salamone et al., ${ }^{25}$ waarin een 1,5 jaar durende interventie bestaande uit groepsbijeenkomsten, een voedingsplan en individuele vervolgcontacten ter bevordering van een gezonde voeding (een verlaging van de (verzadigde) vetconsumptie) en meer bewegen is geëvalueerd, wel een significant effect te zijn op het gewicht en de vetmassa, maar niet op de vetvrije massa. Opvallend was dat alle interventies, met uitzondering van de twee onderzoeken die geen effect hebben gevonden op het gewicht, een multicomponentiele interventie betroffen, waarbij naast aandacht voor gezonde voeding onder meer aandacht was voor meer bewegen. Verder was opvallend dat de enige twee interventies die in een werksetting zijn uitgevoerd ${ }^{30,31}$ significant positieve resultaten toonden. Het effect op de bloeddruk was in zes RCT's onderzocht, ${ }^{19,20,28,30,31,33}$ waarbij sommige onderzoeken het afzonderlijke effect op de diastolische en systolische bloeddruk is gemeten, of waarbij het effect op meerdere momenten is bepaald. Vijf van de zes RCT's onderzochten het effect van een interventie waarbij naast gezonde voeding aandacht was voor andere leefstijlfactoren, zoals bewegen, roken en alcohol.20,28,30,31,33 Met uitzondering van één onderzoek, ${ }^{30}$ waarbij via het bedrijf adviezen werden gegeven, waren er in alle RCT's significant positieve effecten gerapporteerd. Verder waren er in het onderzoek van Steptoe et al. ${ }^{28}$ inconsistente resultaten gevonden van de op gedragsveranderinggebaseerde voorlichting: na 4 maanden was er sprake van een significant gunstig effect op de systolische bloeddruk en een lichte, positieve trend op de diastolische bloeddruk, maar na 12 maanden waren beide effecten verminderd. De meeste effectieve voedingsinterventies waren in de eerstelijn uitgevoerd. Het onderzoek van Stamler et al., ${ }^{31}$ uitgevoerd in een werksetting, is echter eveneens effectief gebleken op zowel de bloeddruk als op de incidentie van hypertensie. Echter, het eerdergenoemde onderzoek van Nisbeth et al., ${ }^{30}$ uitgevoerd in de eerstelijn en specifiek gericht op risicofactoren voor hart- en vaatziekten, had 
geen enkel effect op bloeddruk. Het effect op het cholesterolgehalte in het bloed was in vijf RCT's onderzocht. 19,27,28,30,32 Drie onderzoeken waren uitsluitend gericht op het stimuleren van gezonde voeding; ${ }^{19,27,32}$ de overige twee RCT's betroffen multicomponentiele interventies. 28,30. Vier daarvan ${ }^{19,27,28,30}$ lieten geen effect van de interventie op het cholesterolgehalte zien. In twee hiervan ${ }^{27,28}$ was geen effect op het cholesterolgehalte gevonden, terwijl er wel een significant gunstig effect op vetinname was. De vijfde $\mathrm{RCT}^{32}$ rapporteerde een significant negatieve uitkomst met een sterkere daling van het cholesterolgehalte onder de controlegroep dan onder de interventiegroep.

\section{Effectiviteit op bedrijfsrelevante uitkomstmaten}

Aangezien er geen RCT gevonden is dat het effect op bedrijfsrelevante uitkomstmaten heeft onderzocht, is hiervoor ook gekeken naar gecontroleerde maar nietgerandomiseerde $(\mathrm{CT})$ onderzoeken. Ook hier werd er slechts één gevonden. ${ }^{34}$ In dit onderzoek is een multicomponentieel programma geëvalueerd, waarbij zowel het gebruik van een gezonde voeding als meer lichaamsbeweging gestimuleerd is aan de hand van een viertal modules over lichaamsbeweging en voeding en het verstrekken van e-mailboodschappen, flyers, posters en informatie. Daarnaast kregen de deelnemers een wandelprogramma aangeboden. Binnen dit gecontroleerde onderzoek zijn de effecten op de werktevredenheid en het ziekteverzuim onderzocht. $\mathrm{Er}$ is geen significant effect gevonden op de werktevredenheid, maar wel op het gerapporteerde ziekteverzuim. Het percentage respondenten uit de interventiegroep dat aangaf geen verzuimdagen te hebben opgenomen was toegenomen van $30,9 \%$ voorafgaande aan de interventie naar $67,2 \%$ na afloop van de interventie. Onder de respondenten uit de controlegroep was dit percentage significant minder toegenomen: van $47,5 \%$ naar $51,5 \%$. Verandering in het totale verzuimpercentage blijft in dit onderzoek van Pegus et al. ${ }^{34}$ echter onbeantwoord.

\section{Inventarisatie veldpartijen}

Het Voedingscentrum heeft diverse generieke en specifieke interventies lopen en uitgevoerd. De generieke interventies zijn gericht op de algehele bevolking en hebben vooral tot doel mensen te informeren over gezond eten. De specifieke activiteiten zijn vaak tijdelijk, waarbij veelal een specifieke doelgroep wordt benaderd. Voorbeelden van generieke interventies zijn de campagnes 'Let op vet' (1991-1994), 'Goede Voeding, wat let je?' (1996-2001) en 'Maak je niet dik' (2002-2006). Daarnaast heeft het Voedingscentrum een cd-rom ontwikkeld, waarbij advies-op-maat gegeven wordt over het eetpatroon. Voor het stimuleren van gezonde voeding via de werkplek heeft het NIGZ het bedrijfsvoedingshandboek met vier verschillende modules ontwikkeld. Deze modules behandelen simpele interventies, zoals het ophangen van posters, tot meer intensieve interventies, zoals het opstellen van een persoonlijk voedingsadvies en het aanpassen van het voedingsaanbod in bedrijfskantines. Onderdeel van dit handboek is het 7-stappenplan 'Broodje gezond op het werk'. De NHS houdt zich vooral bezig met actiepakketten voor werknemers ten behoeve van gezonder eten en meer bewegen. De NHS heeft diverse projecten, soms in samenwerking met partners, op het gebied van voeding en andere leefstijlcomponenten, zoals de Nationale GezondheidsTest, Lunchwandelen, en Wereldhartslag en is één van de partners in de 'Maak je niet dik'-campagne van het Voedingscentrum. Het NZO participeert voornamelijk in onderzoeken die vooraf gaan aan interventies. Het NZO stimuleert wetenschappelijk onderzoek naar de relatie tussen zuivel, voeding en gezondheid, organiseert workshops en congressen en brengt het tijdschrift Voedingsmagazine uit.

Uit de gesprekken met de arbodiensten kwam naar voren dat zij vooralsnog geen structurele activiteiten aanbieden ter stimulering van een gezond voedingspatroon. Als reden hiervoor wordt de afwezigheid van de vraag van klanten naar primair preventieve leefstijlprogramma's genoemd en ook het hebben van andere prioriteiten, zoals een hoog ziekteverzuim dat omlaag gebracht dient te worden. Aandacht voor gezonde voeding is vooral incidenteel, bijvoorbeeld in de vorm van het subsidiëren van gezonde lunches gedurende een korte periode of het aansluiten bij bestaande activiteiten zoals de Hartweek van de NHS.

Zoals al uit de voorgaande artikelen is gebleken, worden interventies van bovengenoemde organisaties niet structureel geëvalueerd en als ze al geëvalueerd worden, dan gebeurt dit vaak niet geheel volgens geldende methodologische regels; dat wil zeggen: geen RCT of CT (zie ook www.consort-statement.org). Bij het Voedingscentrum worden de generieke interventies, waarbij het veelal gaat om brochures, geëvalueerd aan de hand van het aantal binnengekomen telefoontjes van burgers en het aantal afgenomen brochures. Van de campagnes 'Let op vet' en 'Goede Voeding, wat let je?' is reeds een proces- en effectevaluatie uitgevoerd. Ook de huidige campagne 'Maak je niet dik' wordt geëvalueerd (door het Erasmus MC, afdeling Maatschappelijke Gezondheidszorg) en de eerste resultaten hebben laten zien dat de meeste mensen een goed bewustzijn hebben van hun (over)gewicht en gemotiveerd zijn om op hun gewicht te letten. ${ }^{35}$ Evaluaties van de programma's of campagnes 
van de NHS worden door andere partijen uitgevoerd, waaronder bijvoorbeeld TNO Kwaliteit van Leven Arbeid die het effect van lunchwandelen onderzoekt.

\section{Discussie}

Toepasbaarheid interventies in de bedrijfsgezondheidszorg

De NVAB wil meer aandacht schenken aan primair preventieve leefstijlinterventies, waaronder voedingsinterventies. Uit de gesprekken met arbodiensten is echter gebleken dat er binnen bedrijven weinig tot niets aan het bevorderen van gezonde voeding gedaan wordt. Er zal dus wat moeten veranderen. De vraag is wat er moet veranderen en vooral hoe. Wellicht kunnen ervaringen met de huisarts als voorbeeld dienen. De huisarts, maar ook de bedrijfsarts, heeft vanwege zijn functie een bepaald aanzien en gezag als gevolg waarvan hij over het algemeen vertrouwen geniet van de patiënt. Het gebeurt echter maar zelden dat de huis- of bedrijfsarts preventief advies verstrekt gericht op het bevorderen of behouden van een gezonde leefstijl of specifieker: gezonde voeding. Veel genoemde belemmeringen hiervoor zijn: een gebrek aan kennis en kunde, en gebrek aan tijd. Deze belemmeringen kunnen eenvoudig weggenomen worden door bijvoorbeeld het opstellen van richtlijnen ten behoeve van gezonde voeding. Hierbij kan gedacht worden aan een richtlijn vergelijkbaar met de CBO-richtlijn voor tabaksverslaving met ruime aandacht voor minimale interventiestrategieën en andere (niet-tijdrovende) mogelijkheden die tot gedragsverandering omtrent gezonde voeding kunnen leiden. Uit ons literatuuroverzicht en de persoonlijke ervaringen van de geïnterviewde veldpartijen is naar voren gekomen dat voedingsadviezen-op-maat effectiever zijn dan algemene voedingsadviezen. Daarbij wordt dan bijvoorbeeld aangesloten bij het huidige eetgedrag van de persoon en de motivatie om te veranderen (naar een gezonder eetgedrag). Bovendien is in diverse onderzoeken een positief effect aangetoond van minimale interventies, uitgevoerd door de huisarts, waarbij een éénmalig, kortdurend, persoonlijk voedingsadvies is verstrekt. Een richtlijn over de wijze waarop het advies verstrekt dient te worden, behoort naar onze mening dan ook tot de mogelijkheden voor de bedrijfsarts om gezonde voeding te stimuleren.

Hoewel verwacht mag worden dat interventies gericht op stimulering van gezonde voeding effectief zijn op de voedingsconsumptie en daarmee tevens nuttig zijn voor de gezondheid, is dit niet uit het onderhavige literatuuronderzoek gebleken. Ondanks dat vier van de zes RCT's een gunstig effect lieten zien op de (diastolische en systolische) bloeddruk, bleek binnen een ander onderzoek het gevonden kortetermijneffect na verloop van tijd weg te ebben en ging een positieve trend zelfs over in een negatieve trend. ${ }^{28}$ Voor cholesterol bleek voor het merendeel van de interventies niet eens een effect aangetoond te kunnen worden en voor lichaamsgewicht waren de effecten alleen zichtbaar indien de voedingsinterventie gecombineerd werd met een interventie gericht op andere leefstijlcomponenten, waaronder hoofdzakelijk beweeginterventies.

In de interviews met de veldpartijen werd aangegeven dat voedingsinterventies pas effectief kunnen zijn als niet alleen de werknemer erin gelooft, maar ook de (bedrijfs) arts. Bij de implementatie van effectief gebleken interventies zal dan ook aandacht moeten worden besteed aan zaken als: het vragen van aandacht voor het probleem, aangeven en demonstreren van het gewenste gedrag en de relevantie ervan op korte en lange termijn, kijkt de werknemer naar de (bedrijfs)arts als deskundig en betrouwbaar persoon, hoe is de toepasbaarheid en de haalbaarheid, et cetera? De werknemer moet overtuigd worden van de persoonlijke relevantie van verandering in zijn of haar voedingsgedrag. Ook is het belangrijk dat de interventie gelijk goed loopt, anders zullen werknemers afhaken. Aangezien beklijving van het gewenste (voedings) gedrag van groot belang is voor het welslagen van een interventie, is het raadzaam om bij de implementatie een procesevaluatie mee te laten lopen voor een eventuele bijsturing.

Naast de hierboven genoemde rol van de bedrijfsarts zal bij het uitvoeren van interventies ook een rol voor andere disciplines, zoals arboverpleegkundigen, zijn weggelegd, waarbij de bedrijfsarts mogelijk als 'regisseur' optreedt.

Ook het bedrijf kan een steentje bijdragen aan een gezonde voeding, bijvoorbeeld via het aanbod in de bedrijfskantine. Immers, 35-40\% van de Nederlandse werknemers kan gebruikmaken van een kantine. ${ }^{36}$ Ondanks dat er concrete minimumeisen en richtlijnen zijn voor het samenstellen van het voedselaanbod bevat $50 \%$ van de maaltijden die in bedrijfskantines worden aangeboden, vleesproducten met een hoog vetgehalte en weinig of geen groenten. ${ }^{37,38}$ Door de werknemer te informeren over het maken van een gezonde lunchkeuze, kan de werknemer bewuster vragen naar 'gezonde' producten, waardoor de cateringmanager mogelijk extra wordt geprikkeld deze 'gezonde' producten aan te bieden. ${ }^{37}$ Voor het informeren van de werknemer kan gedacht worden aan voorlichtingsmateriaal, zoals posters en folders. Uit onderzoek is gebleken dat werknemers die op het werk op hun voedingsgedrag worden gewezen, er gezondere eetgewoonten op na houden. ${ }^{39}$ Het bedrijf kan ook afspraken maken met de cateraar om zodoende het voedingspatroon van de werknemer te 
beïnvloeden. Activiteiten van de werkgever ter bevordering van gezonde voeding worden bovendien zeer gewaardeerd door veel werknemers. ${ }^{39}$

Belemmerende en bevorderende factoren voor toepassing interventies in de bedrijfsgezondheidszorg

Tijdens de gesprekken met de arbodiensten werd gemeld dat zowel bij klanten als bij de arbodiensten regelmatig de vraag opduikt in hoeverre primair preventieve leefstijlinterventies de zorg zijn van de werkgever. Afgevraagd wordt waar de verantwoordelijkheden van de werknemer en de werkgever ophouden, dan wel beginnen. Hoewel de verantwoordelijkheden van de werkgever voor de gezondheid van de werknemer in de arbeidssituatie duidelijk lijken vastgelegd in de arbowetgeving, rijzen vragen over deze verantwoordelijkheden. Is de werkgever verantwoordelijk voor de leefstijlgerelateerde gezondheid van de werknemer en zo ja, hoe ver gaat deze verantwoordelijkheid? Werknemer en werkgever zijn beiden verantwoordelijk voor gezond gedrag op de werkplek. De werknemer moet in zijn vrije tijd zelf zorgen voor een gezonde leefstijl. Mag de werkgever zich bemoeien met het privé-domein van de werknemer? De werkgever is volgens de Arbowet verantwoordelijk voor het gezonde gedrag (niet uitsluitend voor gezonde voeding) voor zover dat de werkplek betreft en kan daartoe de arbeidsvoorwaarden optimaliseren en faciliteiten bieden. ${ }^{38}$ De rol van de arbodiensten hierin is tot op heden helemaal niet duidelijk. Arbodiensten zouden heel goed gezondheidsbevorderende activiteiten kunnen initiëren en daarmee dus actief, in plaats van passief, zoals tegenwoordig nog veelal het geval is, optreden. De reden dat deze actieve opstelling nog geen gewoontegoed is, kan komen door de huidige nadruk op meer secundair preventieve activiteiten, zoals het terugdringen van het ziekteverzuim. ${ }^{38}$ Meer aandacht voor primaire preventie (bijvoorbeeld voorkomen van ziekteverzuim) in plaats van activiteiten gericht op reïntegratie van zieke werknemers is gewenst. De NVAB ondersteunt dit en ziet het belang in van de 'interventie' van de werkgever op de leefstijl van de werknemer, waarbij de bedrijfsarts een belangrijke rol kan vervullen. Bovendien is, gezien het feit dat niet alleen de werknemer maar ook de werkgever met het oog op ziekteverzuim baat heeft bij gezond (leefstijl) gedrag van de werknemer, het delen van de verantwoordelijkheid niet onlogisch.

\section{Conclusies}

1. Voedingsinterventies gericht op het verbeteren van de groente- en fruitconsumptie en/of op het verminderen van de vetconsumptie zijn over het algemeen effectief. Het effect van voedingsinterventies op een toename van de inname van vezels is nog onduidelijk.

2. Interventies gericht op een gezonde voeding hebben uitsluitend een gunstig effect op het lichaamsgewicht indien de interventie tevens gericht is op andere leefstijlaspecten, waaronder voornamelijk het stimuleren van lichaamsbeweging. Het effect op de bloeddruk is echter onduidelijk en bewijs voor een gunstig effect op het cholesterolgehalte ontbreekt vooralsnog.

3. Vanwege een gebrek aan onderzoeken die de effectiviteit op werkgerelateerde uitkomsten hebben onderzocht, kan hierover vooralsnog geen conclusie getrokken worden. Onderzoeken naar het effect van voedingsinterventies op werkgerelateerde uitkomsten zijn dan ook zeer gewenst.

Belangenconflicten: geen gemeld Financiële ondersteuning: ministerie van VWS

\section{Literatuur}

Rissanen A, Heliovaara M, Knekt P, et al. Risk of disability and mortality due to overweight in a Finnish population. BMJ 1990; 301: 835-837.

Nabro K, Jonsson E, Larsson B, et al. Economic consequences of sick-leave and early retirement in obese Swedish women. Int $\mathbf{J}$ Obes 1996; 20: 895-903.

Kreijl CF van, Knaap AGAC. Ons eten gemeten. Gezonde voeding en veilig voedsel in Nederland. RIVM rapportnr 270555007. Houten: Bohn Stafleu van Loghum, 2004.

Brug J, Lechner L. Nederlanders overschatten hun groente- en fruitconsumptie. Voeding 1995; 56: 20-23.

Proper KI, Bakker I, Overbeek K van, et al. Naar een gericht BRAVO-beleid door bedrijfsartsen. Body@Work rapport, april 2005.

Buller DB, Morrill C, Taren D, et al. Randomized trial testing the effect of peer education at increasing fruit and vegetable intake. J Natl Cancer Inst 1999; 91: 1491-1500.

Stevens VJ, Glasgow RE, Toobert DJ. Randomized trial of a brief dietary intervention to decrease consumption of fat and increase consumption of fruits and vegetables. Am J Health Promot 2002; 16: 129-134.

Brug J, Steenhuis I, Assema P van, et al. The impact of a computertailored nutrition intervention. Prev Med 1996; 25: 236-242.

Campbell MK, DeVellis BM, Strecher VJ, et al. Improving dietary behavior: the effectiveness of tailored messages in primary care settings. Am J Public Health 1994; 84: 783-787.

Abood DA, Black DR, Feral D. Nutrition education worksite intervention for university staff: application of the health belief model. Soc Nutr Educ Behav 2003; 35: 260-267.

Campbell MK, Bernhardt JM, Waldmiller M, et al. Varying the message source in computer-tailored nutrition education. Pat Educ Couns 1999; 36: 157-169.

Feldman RHL, Damron D, Anliker J, et al. The effect of the Maryland WIC 5-a-Day promotion program on participants' stages of change for fruit and vegetable consumption. Health Educ Behav 2000; 27: 649-663.

Langeberg P, Ballesteros M, Feldman R, et al. Psychosocial factors and intervention-associated changes in those factors as 
correlates of change in fruit and vegetable consumption in the Maryland WIC 5 a day promotion program. Ann Behav Med 2000; 22: 307-315.

Sorensen G, Stoddard A, Peterson K, et al. Increasing fruit and vegetable consumption through worksites and families in the Treatwell 5-a-day study. Am J Public Health 1999; 89: 54-60.

Sorensen G, Stoddard A, Hunt MK, et al. The effects of a health promotion protection intervention on behavior change: the wellworks study. Am J Public Health 1998; 88: 1685-1690.

Tilley BC, Glan K, Kristal AR, et al. Nutrition intervention for high-risk auto workers: Results of the Next Step Trial. Prev Med 1999; 28: 284-292.

Huxley RR, Lean M, Crozier A, et al. Effect of dietary advice to increase fruit and vegetable consumption on plasma flavonol concentration: results from a randomised controlled intervention trial. J Epidemiol Community Health 2004; 58: 288-289.

Kristal AR, Curry SJ, Shattuck AL, et al. A randomized trial of a tailored, self-help dietary intervention: the Puget Sound eating patterns study. Prev Med 2000; 31: 380-389.

John JH, Ziebland S, Yudkin P, et al. Effects of fruit and vegetable consumption on plasma antioxidant concentrations and blood pressure: a randomised controlled trial. Lancet 2002; 359: 1969-1974.

Appel LJ, Hopkins J, Champagne CM, et al. Effects of comprehensive lifestyle modification on blood pressure control; main results of the PREMIER clinical trial. JAMA 2003; 289: 2083-2093.

Marcus AC, Heimendinger $\mathrm{J}$, Wolfe $\mathrm{P}$, et al. A randomized trial of a brief intervention to increase fruit and vegetable intake: a replication study among callers to the CIS. Prev Med 2001; 33 : 204-216.

Beresford SAA, Thompson B, Feng Z, et al. Seattle 5 a day worksite program to increase fruit and vegetable consumption. Prev Med 2001; 32: 230-238.

Sorensen G, Morris DM, Hunt MK, et al. Work-site nutrition intervention and employees' dietary habits: the treatwell program. Am J Public Health 1992; 82: 877-880.

Kreuter MW, Strecher VJ. Do tailored behavior change messages enhance the effectiveness of health risk appraisal? Results from a randomized trial. Health Educ Res 1996; 11: 97-105.

Salamone LM, Cauley JA, Black DM, et al. Effect of a lifestyle intervention on bone mineral density in premenopausal women: a randomized trial. Am J Clin Nutr 1999; 70: 97-103.
Bourdeaudhuij I De, Brug J. Tailoring dietary feedback to reduce fat intake: an intervention at the family level. Health Educ Res 2000; 15: 449-462.

Beresford SAA, Curry SJ, Kristal AR, et al. A dietary intervention in primary care practice: the eating patterns study. Am J Public Health 1997; 87: 610-616.

Steptoe A, Doherty S, Rink E, et al. Behavioural counselling in general practice for the promotion of healthy behaviour among adults at increased risk of coronary heart disease: randomised trial. BMJ 1999; 319: 943-948.

O'Halloran P, Lazovich CA, Patterson RE, et al. Effect of health lifestyle pattern on dietary changes. Am J Health Promot 2001; 16: 27-33.

Nisbeth O, Klausen K, Andersen LB. Effectiveness of counselling over 1 year on changes in lifestyle and coronary heart disease risk factors. Pat Educ Couns 2000; 40: 121-131.

Stamler R, Stamler J, Gosch FC, et al. Primary prevention of hypertension by nutritional-hygienic means. JAMA 1989; 13: 1801-1807.

Reynolds KD, Gillum JL, Hyman DJ, et al. Comparing two strategies to modify dietary behaviour and serum cholesterol. J Cardiovasc Risk 1997; 4: 1-5

Stevens VJ, Obarzanek E, Cook NR, et al. Long-term weight loss and changes in blood pressure: results of the trials of hypertension prevention, phase II. Ann Intern Med 2001; 134: 1-11.

Pegus C, Bazzarre TL, Brown JS, et al. Effect of the heart at work program on awareness of risk factors, self-efficacy, and health behaviours. J Occup Environ Med 2002; 44: 228-236.

Wammes B, Breedveld B, Brug H. Mensen zijn zich bewust van overgewicht en bereid iets eraan te doen. Voeding Nu 2003; 11 : 26-27.

Vaandrager L, Evans CM. Gezondheidsbevordering op de werkplek. In: Walburg JA, Vaandrager L (red). Leefstijl en werk. Houten: Bohn Stafleu van Loghum, 2001.

Dalen A van, Tienstra M. Gezond en lekker in bedrijfsrestaurants. Voeding Nu 2001; 1: 24-25.

Singh AS, Poppel MNM van, Seidell JC, et al. Lichamelijke activiteit en ongezond voedingsgedrag onder werknemers. Gezondheid en gedrag: debatten en achtergrondstudies. Zoetermeer: RVZ rapport, 2002.

Kroodsma A, Hekman M, Kuppens R. Voorlichting over gezonde voeding op de bedrijfsvloer werkt. Voeding Nu 2000; 5: 29-31. 